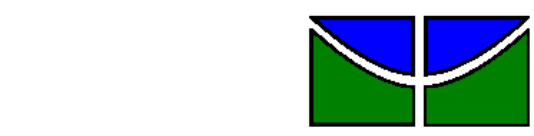

Universidade de Brasília

Faculdade de Economia, Administração e Contabilidade

Departamento de Administração

Curso de Graduação em Administração a distância

ROBERT MUZY FURTADO

\title{
A INFLUÊNCIA DAS PRÁTICAS SUSTENTÁVEIS DE GESTÃO NA IMAGEM CORPORATIVA: Um estudo de caso de um shopping center em Brasília
}

Brasília - DF 
ROBERT MUZY FURTADO

\section{A INFLUÊNCIA DAS PRÁTICAS SUSTENTÁVEIS DE GESTÃO NA IMAGEM CORPORATIVA: Um estudo de caso de um shopping center em Brasília}

Monografia apresentada à Universidade de Brasília (UnB) como requisito parcial para obtenção do grau de Bacharel em Administração.

Professora Orientadora:

Mariana Marlière Létti - Mestre em Antropologia Social 
Furtado, Robert Muzy.

A Influência das práticas sustentáveis de gestão na imagem corporativa: Um estudo de caso de um shopping center em Brasília / Robert Muzy Furtado. - Brasília, 2010.

47 f.il.

Monografia (bacharelado) - Universidade de Brasília, Departamento de Administração - EaD, 2010.

Orientadora: Prof. ${ }^{\mathrm{a}}$ MSc. Mariana Marlière Létti.

1. ISO 14001. 2. Gestão ambiental. 3. Imagem corporativa. 4. Shopping center. I. Título. 
ROBERT MUZY FURTADO

\title{
A INFLUÊNCIA DAS PRÁTICAS SUSTENTÁVEIS DE GESTÃO NA IMAGEM CORPORATIVA: Um estudo de caso de um shopping center em Brasília
}

A Comissão Examinadora, abaixo identificada, aprova o Trabalho de Conclusão do Curso de Administração da Universidade de Brasília do aluno

\section{Robert Muzy Furtado}

\author{
Prof. ․ MSc Mariana Marlière Létti \\ Professora-Orientadora

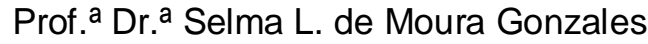 \\ Professora-Examinadora \\ Prof. ${ }^{\text {a }}$ MSc Neuza da Silva Oliveira \\ Professora-Examinadora
}


Ao Senhor Jesus, meu benchmark. 
Agradeço a Deus, aos meus pais e aos professores e tutores que contribuíram para minha formação acadêmica; e à administração do Pátio Brasil Shopping pela atenção e auxílio prestados. 
"A natureza, para ser comandada, precisa ser obedecida."

Francis Bacon 


\section{RESUMO}

A gestão ambiental consiste em um assunto atual e urgente, visto que o modelo de produção capitalista atraiu diversas consequências para o meio ambiente. Nesse cenário, os objetivos de maximização do lucro têm sido questionados, tendo em vista a preocupação cada vez maior das organizações na adoção de medidas que minimizem o uso de recursos de maneira que estes não se estraguem de modo irreversível ou se acabem permanentemente. A consciência ecológica está se desenvolvendo nas sociedades, exigindo uma nova postura no meio empresarial. Diante das pressões sociais, a empresa que ignora a sustentabilidade tende a prejudicar sua imagem corporativa. Este trabalho objetiva avaliar a influência das práticas sustentáveis de gestão na imagem de um shopping center, considerando informações obtidas com o responsável pelo Sistema de Gestão Ambiental da empresa e opiniões de clientes e consumidores. Por meio das pesquisas qualitativa e quantitativa utilizadas, chegou-se à conclusão de que a adoção da certificação ISO 14001, além do emprego de ações e práticas ambientais, não gera vantagens competitivas significativas para a empresa estudada. Todavia, tal modelo de gestão promove conscientização e mudança de atitudes nos consumidores incentivando, principalmente, os mais jovens a se preocuparem com a questão ambiental.

Palavras-chave: ISO 14001; gestão ambiental; imagem corporativa; shopping center. 


\section{LISTA DE ILUSTRAÇÕES}

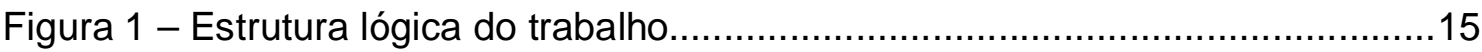

Figura 2 - Conhecimento das ações ambientais - Consumidores .............................35

Figura 3 - Preferência dos consumidores - faixa etária ………………………....36

Figura 4 - Preferência dos consumidores - grau de instrução. .................................36

Figura 5 - Influência da ISO 14001 - faixa etária …………..................................37

Figura 6 - Influência da ISO 14001 - grau de instrução. ........................................37

Figura 7 - Influência das práticas ambientais - faixa etária......................................38

Figura 8 - Influência das práticas ambientais - grau de instrução .............................38 


\section{LISTA DE TABELAS}

Tabela 1 - Faixa etária dos participantes.................................................33

Tabela 2 - Grau de instrução dos participantes ............................................. 33

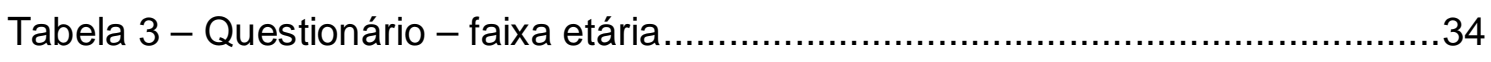

Tabela 4 - Questionário - grau de instrução............................................ 


\section{SUMÁRIO}

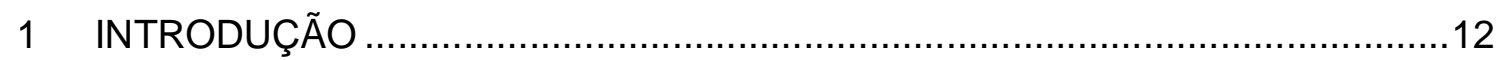

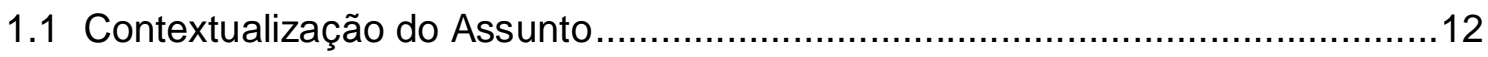

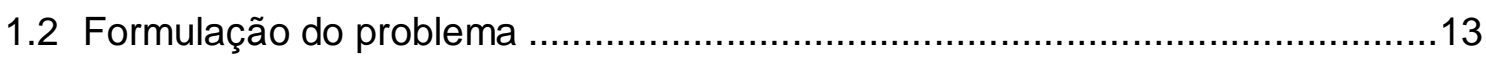

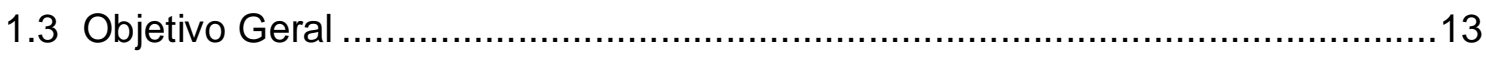

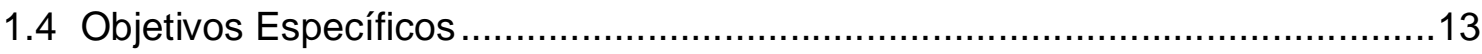

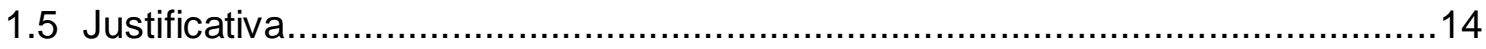

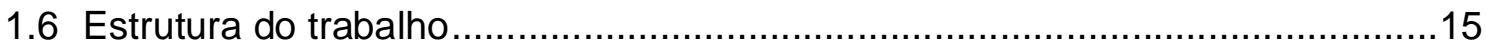

2 REFERENCIAL TEÓRICO ..............................................................................

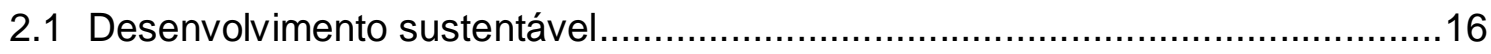

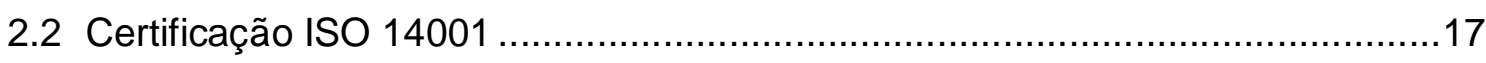

2.3 Sistema de gestão ambiental ...................................................................17

2.4 Motivos que levam organizações a implantarem um SGA …............................18

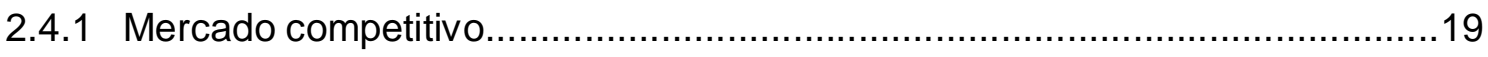

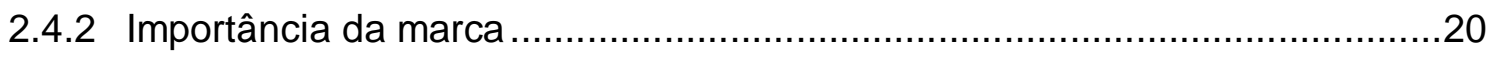

2.5 Benefícios gerados com a implantação de um SGA ……………………........20

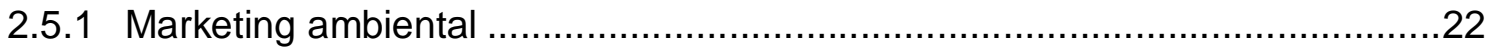

2.5.2 Vantagens competitivas da gestão ambiental .........................................23

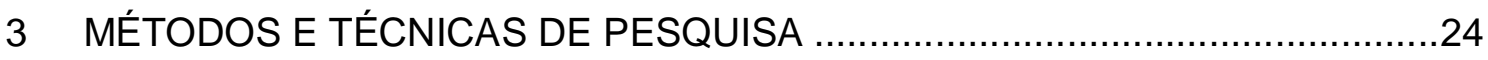

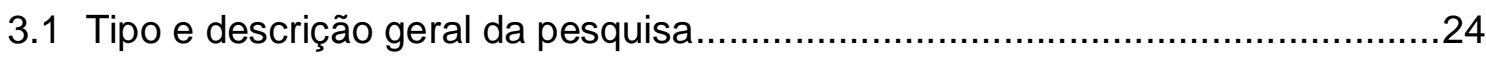

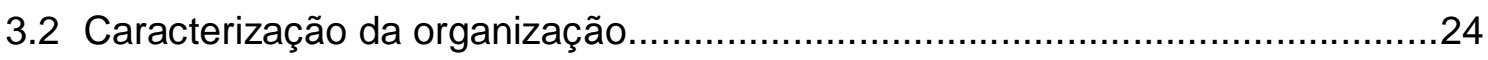

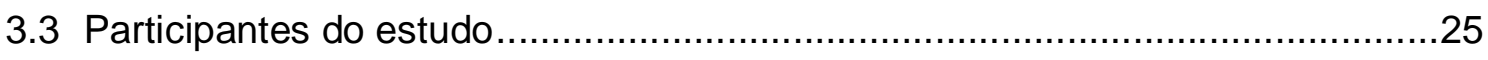

3.4 Caracterização dos instrumentos de pesquisa................................................26

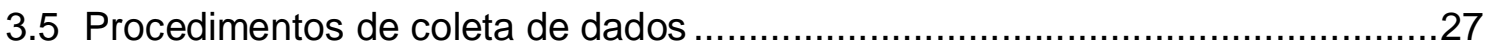

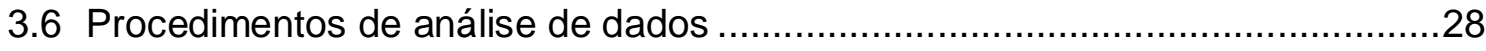

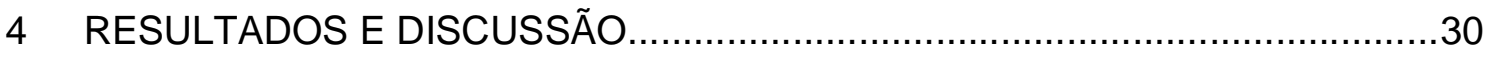


4.1 Análise de conteúdo da entrevista .........................................................

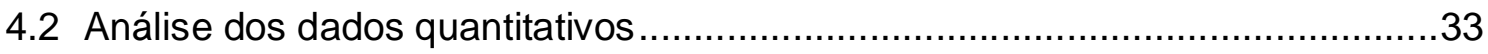

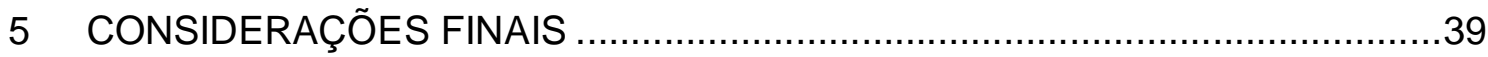

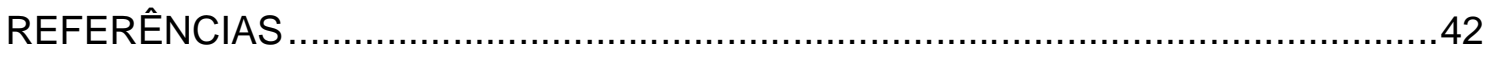

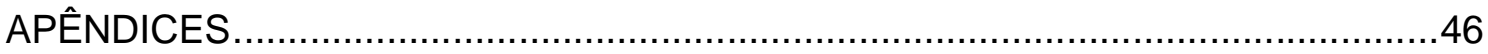

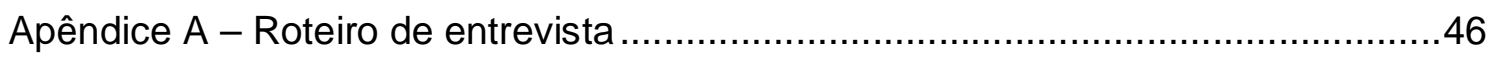

Apêndice B - Questionário - Consumidores do Pátio Brasil ...............................48 


\section{INTRODUÇÃO}

\subsection{Contextualização do assunto}

A responsabilidade das organizações em relação ao meio ambiente tem ganhado cada vez mais espaço no gerenciamento empresarial. A sustentabilidade está deixando de ser praticada por imposições legais ou pressões de ambientalistas para ser uma prática voluntária das empresas com o escopo de obterem vantagens competitivas. A consciência ecológica tem se desenvolvido na sociedade, e a organização que não buscar se adequar às práticas sustentáveis de gestão tende a perder competitividade, visto que grande parte dos consumidores exige por parte da empresa uma postura ambiental como, por exemplo, produção limpa, economia dos recursos naturais, destinação ecologicamente correta dos resíduos, e que a corporação contribua para a redução da emissão de CO2 na atmosfera.

Em virtude dessa evolução da consciência ambiental por parte da sociedade, novas políticas e regulamentações têm surgido pressionando as organizações a empregarem medidas que reduzam os impactos ambientais. Com a implantação dessas medidas, as empresas têm em vista a externalização de uma imagem de preocupação com o meio ambiente.

Diante disso, a adoção de um Sistema de Gestão Ambiental torna-se uma fonte de estratégia para construção de uma boa imagem corporativa. Destinar parte dos investimentos à preservação do meio ambiente deve ser a nova visão das empresas. Seus objetivos, sua missão, suas estratégias de marketing, a organização como um todo deve se adaptar ao mercado corretamente ecológico.

O desenvolvimento a partir de um modelo essencialmente capitalista, que visa ao máximo de lucro, tem sido substituído, com o passar dos anos, pela visão de que investir em sustentabilidade, além de suprir necessidades sem prejudicar as gerações futuras, proporciona grande vantagem em meio a um mercado aberto e competitivo, influenciando positivamente a imagem da corporação. 


\subsection{Formulação do problema}

No entendimento de Chiele (2003), vários são os motivos pelos quais as organizações buscam a certificação de seus sistemas de gestão ambiental. Esses motivos podem ser a obtenção de vantagem competitiva, 0 atendimento a exigências do mercado, a diminuição do risco de multas relacionadas a impactos ambientais, ou ainda a redução do consumo de água e energia.

Para se implementar um sistema de gestão ambiental, são necessários investimentos, cujos custos variarão de acordo com o tipo de negócio e tamanho da organização. O problema que este trabalho buscará responder é: vale a pena investir em gestão ambiental com o fim de adquirir vantagem competitiva pelo devido reconhecimento da sociedade?

\subsection{Objetivo Geral}

O objetivo do presente estudo é avaliar até que ponto as práticas sustentáveis de gestão promovem vantagem competitiva para a empresa pelo devido reconhecimento da sociedade.

\subsection{Objetivos Específicos}

A partir do objetivo geral proposto, foram definidos os seguintes objetivos específicos:

- Descrever como a adoção do certificado ISO 14001 promove vantagens para a organização; 
- Verificar como as práticas sustentáveis interferem na imagem de um shopping center;

- Identificar de que maneira a gestão ambiental influencia o público consumidor.

\subsection{Justificativa}

As sociedades estão compreendendo que os recursos naturais são finitos. As organizações e as leis têm acompanhado a tendência mundial de promover a preservação do meio ambiente. Todavia, mesmo com o pensamento de que a vida na Terra encontra-se ameaçada, muitos gestores resistem à adoção das práticas ambientais por verem os sistemas de gestão ambiental como altamente dispendiosos.

Como se verá no referencial teórico deste trabalho, inúmeros autores têm relatado mudanças na sociedade no que concerne à preocupação com os impactos ambientes gerados pelas organizações. Entretanto, a gestão ambiental como fonte geradora de vantagem competitiva não predomina na visão das empresas, uma vez que 0 antigo paradigma, no qual se visualiza a gestão ambiental como fonte de despesas, ainda está na mentalidade de muitas organizações (EPELBAUM, 2004).

Sob esse panorama, a justificativa da pesquisa proposta não se baseia na reflexão no que tange à destruição da natureza ou ao esgotamento dos recursos naturais, mas sim no fato de que a gestão ambiental pode ser um investimento lucrativo para a empresa. Diante disso, este estudo visa à compreensão de como a adoção de práticas sustentáveis influencia a imagem de um shopping center, o que pode estimular o surgimento de mais pesquisas envolvendo outros tipos de organizações.

Ao se analisar os resultados deste trabalho, pode-se adaptar as conclusões a outras organizações que não sejam shopping centers, adotando-se estratégias que construam ou melhorem a imagem da corporação funcionando como um marketing estratégico. É nesse contexto que a organização que considera a preservação ambiental em sua visão, missão e valores gera para si maiores chances de sobrevivência e crescimento. 


\subsection{Estrutura do tabalho}

Esta monografia está estruturada em cinco capítulos. O primeiro apresenta a introdução do trabalho, expondo a formulação do problema de pesquisa, a justificativa da pesquisa e seus objetivos. $O$ capítulo seguinte busca nutrir o presente estudo com análises e conceitos relacionados à gestão ambiental e a imagem corporativa elaborados por diversos autores. O terceiro capítulo descreve detalhadamente os métodos a serem utilizados, cujos resultados são apresentados e analisados no quarto capítulo mediante tabelas e gráficos. O último capítulo trata das considerações finais deste trabalho, demonstrando as conclusões relacionadas a cada objetivo específico proposto.

A figura 1 apresenta a estrutura lógica deste trabalho:

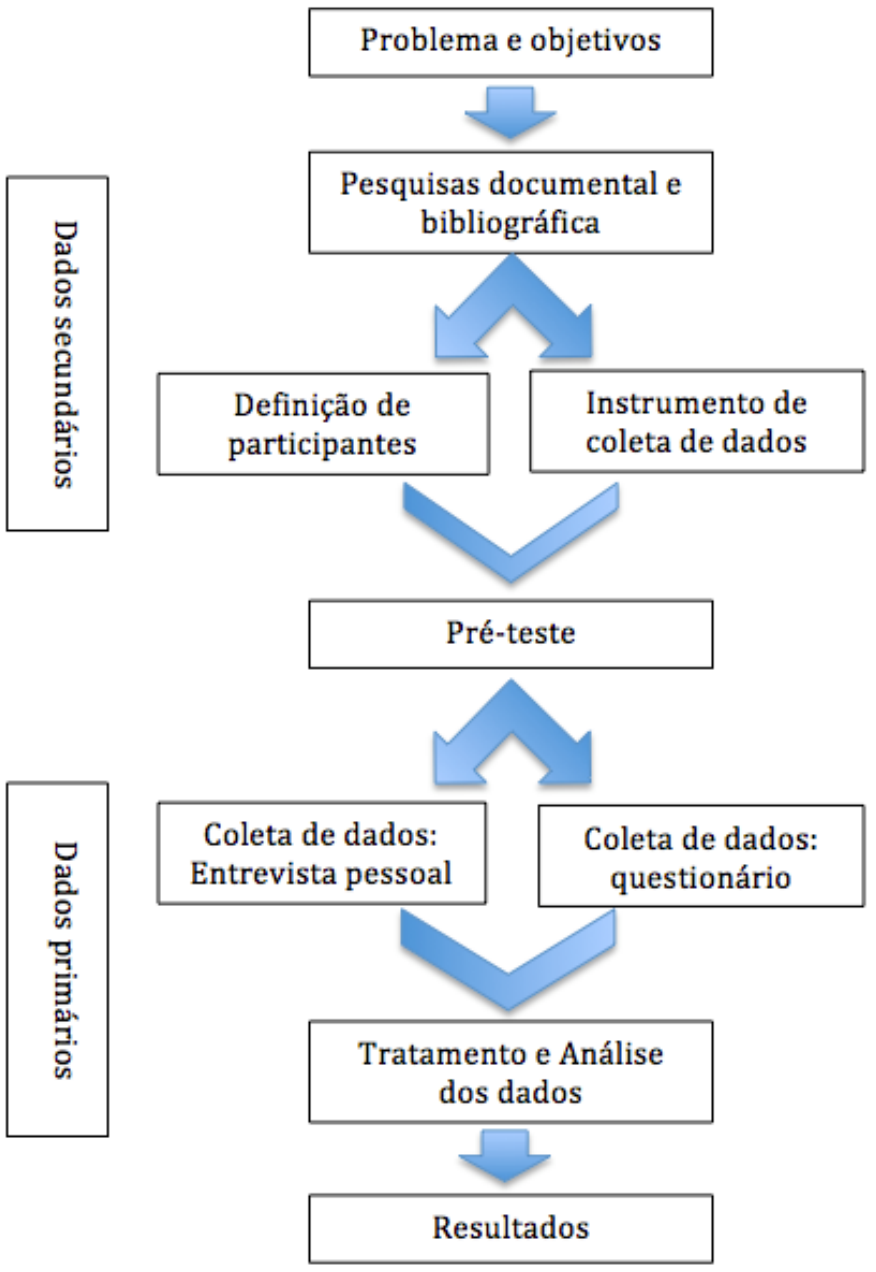

Figura 1: Estrutura lógica do trabalho Fonte: Elaborada pelo autor 


\section{REFERENCIAL TEÓRICO}

\subsection{Desenvolvimento sustentável}

Sob o ponto de vista econômico, nunca houve tanta riqueza no planeta. Embora o progresso melhore a qualidade de vida da humanidade, o modelo atual de crescimento econômico deu origem a um grave desequilíbrio com o meio ambiente. Foi a partir desse cenário que surgiu a discussão sobre desenvolvimento sustentável.

De acordo com Donaire (1999), a propagação da poluição ambiental, a qual afeta todos os seres humanos por meio da apropriação indevida de água, ar e solo, foi provocada pelo fato de os recursos naturais serem classificados como bens livres, em que não é preciso trabalho para sua obtenção. Isso atrapalhou no estabelecimento de critérios na exploração do meio ambiente.

Raynaut e Zanoni (1993) definem desenvolvimento sustentável como o desenvolvimento que satisfaz as necessidades da geração atual, sem comprometer a capacidade das gerações futuras de satisfazerem as suas. Já Espinosa (1993, apud MOURA JUNIOR, 1997, pág. 33) traz um conceito mais completo. Para ele:

o desenvolvimento sustentável é um processo de transformação no qual a exploração dos recursos, a direção dos investimentos, a orientação do desenvolvimento tecnológico e a mudança institucional se harmonizam e reforçam o potencial presente e futuro, a fim de atender as necessidades e aspirações humanas.

No entendimento de Rossi (2008), é de grande importância que se adapte a questão ambiental às exigências do mercado mundial, estabelecendo políticas de desenvolvimento voltadas para a sustentabilidade. Para Epelbaum (2004), vale destacar que essas políticas agregam os benefícios dos sistemas de gestão ambientais, associados às tecnologias ambientais mais limpas e melhores produtos. 


\subsection{Certificação ISO 14001}

A ISO 14001, elaborada pela International Organization for Standardization (ISO) é uma das normas internacionais de caráter voluntário, a qual foi desenvolvida com o fim de auxiliar as empresas a equilibrar os impactos gerados por suas atividades ao meio ambiente ou à saúde dos trabalhadores com suas necessidades econômicas (CERQUEIRA; MARTINS, 2005).

A NBR Série ISO 14001 especifica os requisitos para que um Sistema de Gestão Ambiental (SGA) capacite a organização a implementar uma política ambiental e possa ser aplicada em qualquer tipo e porte de organização (ABNT, 2004).

As empresas buscam essa certificação com o objetivo de legitimar suas práticas sustentáveis. De acordo com Rossi (2008), os princípios que definem um sistema de gestão ambiental com base na ISO 14001 são: política ambiental; planejamento; implementação e operação; verificação e ação corretiva; e análise crítica.

\subsection{Sistema de gestão ambiental}

Para que as ações voltadas à sustentabilidade sejam implantadas, é necessário que a organização implemente um sistema de gestão ambiental, o qual é definido pela Associação Brasileira de Normas Técnicas - ABNT (1996, p.37):

SGA é a parte do sistema de gestão global que inclui a estrutura organizacional, o planejamento de atividades, responsabilidades, práticas, procedimentos, processos e recursos para o desenvolvimento, implantação, alcance, revisão e manutenção da política ambiental.

Segundo Macedo e Oliveira (2005), o SGA consiste em uma estratégia empresarial que, através de planos e programas de caráter preventivo, visa pôr em harmonia a preservação ambiental com a lucratividade. Os autores acrescentam que ao se adotar um SGA, surgem diversos conflitos e resistências à sua implantação, pois trata-se de uma mudança cultural, necessitando de clara disposição dos 
gestores. Já Kraemer (2010) destaca que o objetivo principal do SGA é eliminar ou minimizar os impactos à natureza através de ações mitigadoras, além de buscar o melhor relacionamento possível com o meio ambiente.

No que concerne à origem do SGA, Kraemer (2010) expõe que o mesmo surgiu com o desenvolvimento dos sistemas de qualidade; e sobre seu funcionamento, o autor descreve que um SGA deve estabelecer procedimentos e instruções de trabalho que garantam a execução da política ambiental e o alcance das metas. Para se estabelecer esse sistema, todos os fatores relacionados com atividades, serviços e produtos das organizações e os impactos que estes causam ao ambiente, devem ser identificados baseando-se na legislação e outros instrumentos legais e normativos. Adotar um SGA não é obrigatório, porém, o mercado mundial tem exigido, a cada dia mais, certificações formais de gestão ambiental como condição de comercialização. Diante disso, embora, muitas vezes, adotar um SGA implique em uma complexa mudança estrutural, as empresas, de acordo com Rossi (2008), tem se esforçado em sua implantação, com o fim de obterem reconhecimento da qualidade ambiental dos produtos ou serviços oferecidos, com base em normas certificadas internacionalmente.

\subsection{Motivos que levam organizações a implantarem um SGA}

Após o início das discussões em relação ao meio ambiente, as organizações passaram a conviver com pressões intensas que, segundo Macedo e Oliveira (2005, pag. 131), "até o início da década de 1970, eram inimagináveis". A partir daí, as organizações continuaram visando ao lucro, porém, as que permaneceram lucrando de forma predatória passaram a receber sanções das autoridades governamentais.

Acerca das razões pelas quais as organizações buscam melhorar sua performance ambiental, inúmeros autores explicam com diferentes opiniões.

Souza (2002) defende que são basicamente três as razões: as mudanças do regime regulatório internacional no que tange à proteção ambiental; as mudanças do mercado; e as mudanças do nível de conhecimento, com as crescentes descobertas e divulgações em relação a causas e consequências de danos ambientais. 
Já Macedo e Oliveira (2005) afirmam que as razões que levam organizações a implantar um SGA, normalmente são: necessidade de obedecerem às leis; necessidade de se tornarem mais eficazes, reduzindo custos com reciclagem e evitando desperdícios; necessidade de serem mais competitivas; e necessidade de não comprometerem sua imagem junto à opinião pública.

Dessa maneira, adotar um Sistema de Gestão Ambiental pode se caracterizar como uma resposta às pressões dos investidores, acionistas, consumidores e da concorrência, com o fim de assegurar continuidade no mercado (MACEDO; OLIVEIRA, 2005).

\subsubsection{Mercado competitivo}

O conceito de competitividade tem se tornado cada vez mais importante, haja vista as céleres transformações do mercado e a concorrência empresarial mais acirrada nos últimos tempos. Para Rossi (2008), em razão das mudanças do mercado, novas oportunidades e ameaças surgem, e a complexidade do ambiente mercadológico e as exigências do consumidor têm aumentado. Nesse ínterim, as organizações vêm buscando, com o objetivo de continuarem competitivas, uma interação maior com seus clientes. O autor assevera ainda, que é imprescindível que a empresa se torne mais aberta a receber novas ideias, uma vez que o sucesso estratégico depende da criação e renovação de pensamentos que gerem vantagem competitiva.

Sob essa ótica, as empresas e seus fornecedores, além de seus concorrentes e clientes, de acordo com Kotler (2000, p.160), "operam em um macroambiente de forças e tendências que dão forma a oportunidades e impõem ameaças". Para o autor, pelo fato dessas forças e tendências não serem controláveis, as empresas precisam monitorá-las e responder a elas. Com o objetivo de envolver esse macroambiente, Rossi (2008) aponta que as organizações devem desenvolver métodos que criem ou fortaleçam sua imagem, agregando as qualidades que destaquem a relação da marca com o consumidor. 


\subsubsection{Importância da marca}

A marca, no entendimento de Pinho (1996), consiste em um nome, sinal ou desenho que identifique os produtos ou serviços de uma empresa e os diferencie dos da concorrência. Assim, Rossi (2008) afirma que fortalecer a marca favorece a competitividade, e para consolidar uma marca, é fundamental que se crie uma identidade corporativa. A marca deve projetar uma imagem forte e que seja reconhecida e interpretada positivamente pelo consumidor.

Sobre esse assunto, Kotler (2000, p. 318) acrescenta que "a imagem é afetada por muitos fatores que a empresa não pode controlar", e a identidade corporativa relaciona-se com a maneira que o consumidor vê a organização e seus produtos. Já Diefenbach (1987, apud PINHO, p.156) afirma que "como uma marca, a identidade corporativa diferencia a empresa de modo positivo e memorável, projetando assim uma personalidade única e posicionando adequadamente a companhia no mercado".

Segundo Tavares (1998), a diferenciação bem-sucedida da marca exige algo especial que possa conquistar a preferência do mercado. Nesse enfoque, a empresa deve mudar alguns posicionamentos de acordo com o ambiente externo para que não se perca a liderança e preferência.

Dessa maneira, é por meio da marca na visão do público que a organização se posiciona no mercado e pode consolidar uma forte imagem de responsabilidade social corporativa.

\subsection{Benefícios gerados com a implantação de um SGA}

$\mathrm{Na}$ literatura pertinente, vários autores publicaram estudos relacionados aos benefícios de se administrar com consciência ecológica. Os estudos da United Nations Environment Programme - UNEP (2001) e do Instituto Ethos (2003) concluem que o valor da marca e a reputação é o critério mais positivamente relacionado com a gestão ambiental nos países desenvolvidos. Já nos países 
emergentes, os principais benefícios estão na redução de custos e ampliação a novos mercados.

A associação WBCSD (1997) destaca que a consciência ecológica pode afetar positivamente o resultado financeiro da organização, citando quinze exemplos de empresas que obtiveram benefícios diversos.

Os estudos da UNEP (2001, apud EPELBAUM, 2004, p. 105) concluem que "na pior hipótese, o impacto da gestão ambiental sobre o valor ao acionista é nulo, e na melhor hipótese pode aumentar o seu valor".

Donaire (1996, p.49), em seu estudo sobre gestão ambiental, afirma que:

(...) essa atividade pode se transformar em excelente local de oportunidades de redução dos custos. Isto pode ser viabilizado ou através de reaproveitamento de reciclagem ou por meio da descoberta de novos componentes e novas matérias-primas que resultem em produtos mais confiáveis e tecnologicamente mais limpos. Essa repercussão fica fácil de ser compreendida se entendermos que qualquer melhoria conseguida no nível de efluentes da empresa sempre representará, de alguma forma, certo ganho de energia ou de matéria contida no processo de produção.

Já Callenbach et al. (1993) lista seis benefícios da gestão ambiental:

- Sobrevivência humana - segundo o autor, sem uma economia ambiental, a sobrevivência do homem estará ameaçada;

- Consenso público - sem consenso entre a comunidade de negócios e o povo, a economia de mercado estará politicamente ameaçada;

- Oportunidade de mercado - a gestão com consciência ecológica pode aumentar as oportunidades de mercado, de acordo com o autor;

- Redução de riscos - os riscos de responsabilização por danos ambientais, os quais envolvem grandes somas de dinheiro, são reduzidos;

- Redução de custos - pode-se diminuir gastos como o consumo de energia e água, por exemplo;

- Integridade pessoal - de acordo com o autor, os gestores e funcionários terão a sensação de integridade pessoal, identificando-se totalmente com seu trabalho. 
E, finalmente, Dyllick (2000) aponta uma série de benefícios, os quais irão depender do grau de aplicação das práticas sustentáveis por parte da empresa. $\mathrm{O}$ autor classifica esses benefícios como internos e externos. Internamente, a gestão ambiental pode: melhorar as medidas já existentes; aumentar a motivação dos colaboradores; prevenir quanto a riscos de problemas ambientais; e reduzir custos. Externamente, esse tipo de gestão pode: melhorar a imagem corporativa da organização; promover vantagem competitiva; promover vantagens perante seguradoras e bancos; e facilitar negócios com órgãos ambientais.

\subsubsection{Marketing ambiental}

Marketing consiste no processo de planejamento e realização do conceito, preço, comunicação e distribuição de idéias, produtos ou serviços, criando trocas que satisfaçam necessidades ou objetivos organizacionais e pessoais (SEMENIK; BAMOSSY, 1996).

O marketing ambiental surgiu com o fim de melhorar a imagem corporativa, assegurando lucratividade no processo produtivo e protegendo o meio ambiente (ROSSI, 2008).

De acordo com Vaz (2000), existe um número cada vez maior de consumidores que adquirem apenas produtos que não gerem danos ao ambiente $e$ que não sejam nocivos à vida. Nesse cenário, criou-se um novo conceito de marketing, o qual permite um processo produtivo desenvolvido por tecnologia moderna, mas compatível com o equilíbrio ecológico. Para Rossi (2008), muitas empresas têm atraído clientes pela produção de bens das linhas verdes, conhecidos como menos prejudiciais ao meio ambiente. Segundo o autor, esta tendência é um fenômeno do marketing, e esses clientes não se preocupam somente com a satisfação de suas necessidades, mas também com a sustentabilidade e a responsabilidade social.

Rossi (2008) acrescenta ainda que, ao adotar o marketing ambiental, a empresa precisa comunicar seus clientes sobre os benefícios gerados ao se adquirir 
bens ou serviços ambientalmente responsáveis, incitando o desejo do mercado por esse tipo de produto.

\subsubsection{Vantagens competitivas da gestão ambiental}

A competitividade refere-se ao quanto uma organização é eficaz e eficiente, comparando-a às concorrentes. Enquanto a eficácia está relacionada à qualidade dos produtos, à posição no mercado e à lucratividade, a eficiência trata da velocidade de resposta e dos custos baixos (CZINKOTA, 2001).

Para Hojda (1998), as empresas têm as vantagens competitivas como motivação principal para investirem em um sistema de gestão ambiental, uma vez que esse investimento possibilita a conquista de mercados restritos e mais facilidade na obtenção de financiamentos junto a organismos internacionais.

No entendimento de Novaes (1991), as portas do mercado e do lucro estarão cada vez mais abertas para organizações que não poluem ou poluem menos, prejudicando as que visam a maximizar lucros rejeitando a consciência ecológica.

$\mathrm{Na}$ época atual, essas empresas que desprezam as questões ambientais são julgadas e condenadas pela opinião pública, comprometendo sua sobrevivência. Percebe-se então que a gestão ambiental se tornou uma vantagem competitiva indispensável (HOJDA, 1998). 


\section{MÉTOdOS E TÉCNICAS DE PESQUISA}

\subsection{Tipo e descrição geral da pesquisa}

A respeito de métodos e técnicas de pesquisa, Minayo (1996) ressalta que a metodologia em ciências sociais consiste na escolha do caminho do pensamento a ser seguido. Para o autor, trata-se de um "conjunto de técnicas que possibilitam a apreensão da realidade" (p. 22). Ao escrever sobre o assunto, Godoy (1995) descreve as principais características de uma pesquisa qualitativa, as quais servem de base para este estudo. Ele cita que esse tipo de pesquisa possui caráter descritivo, e que nela "o processo é o foco principal de abordagem e não o resultado ou o produto" (p. 58). Nesse contexto, a pesquisa qualitativa busca identificar a realidade de acordo com a visão dos participantes, sem a utilização de elementos estatísticos para a análise dos dados, empregados pela pesquisa quantitativa.

Para a realização do presente estudo, optou-se primeiramente pela utilização da pesquisa qualitativa visando à obtenção de informações acerca da influência das práticas sustentáveis de gestão na imagem do Pátio Brasil Shopping. Contudo, verificou-se que para se conseguir uma análise mais satisfatória era preciso comparar essas informações com a medição das opiniões e preferências do público frequentador do shopping. Por conseguinte, surgiu a necessidade de se adotar também uma pesquisa quantitativa, a qual buscou obter dados precisos que permitissem uma análise estatística.

\subsection{Caracterização da organização}

A organização escolhida como objeto deste estudo localiza-se no Setor Comercial Sul de Brasília, no Distrito Federal, e conta com uma circulação média de oitenta mil consumidores por dia. Trata-se de um shopping que possui cinco pavimentos, com mais de duzentas lojas e diversas opções de refeições em sua 
praça de alimentação. O alto número de pessoas que circulam no local deve-se à proximidade com escolas, escritórios e com a rodoviária de Brasília.

Inaugurado em 1997, o Pátio Brasil Shopping é certificado pela ISO 14001, e compromete-se a utilizar a norma de acordo com suas especificações. Sua política consiste em uma maneira de formalizar que a empresa é geradora de resíduos e que Ihes dará uma destinação correta (PÁTIO BRASIL SHOPPING, 2010).

A organização é administrada pelo grupo português Sonae Sierra, e conta com 65 mil metros quadrados de área construída, sendo 33 mil apenas de lojas. Há 240 operações comerciais, 6 salas de cinema, 7 lojas âncoras e 27 lojas de alimentação.

Buscando a mais alta qualificação em gestão ambiental formalizada, o Pátio Brasil adotou ações que o tornaram o primeiro shopping da região Centro-Oeste a conquistar a certificação ISO 14001. Dentre essas ações, que visam à preservação do planeta, destacam-se a sua atuação em conformidade com a legislação e normas ambientais e a coleta seletiva do lixo produzido em todas as lojas e instalações. Outra preocupação do shopping é alcançar em breve a certificação da Occupational Health and Safety Assessment Services, a OHSAS 18001, a qual consiste em um sistema de gestão que abarca segurança ocupacional e saúde.

\subsection{Participantes do estudo}

Para participar do estudo, foi convidado um engenheiro de operações que atuasse na administração do shopping, com o escopo de se obter informações exatas no que diz respeito ao funcionamento da gestão ambiental na estrutura da organização. Para a aplicação do questionário estruturado participaram de maneira aleatória 429 homens e mulheres que frequentam ou já frequentaram o shopping, de diferentes faixas etárias. 


\subsection{Caracterização dos instrumentos de pesquisa}

O presente trabalho foi desenvolvido inicialmente por meio de uma pesquisa bibliográfica a respeito das vantagens da implantação de um Sistema de Gestão Ambiental. Com essa pesquisa procurou-se definir os aspectos a serem abordados e os instrumentos de coleta de dados. De acordo com Mattar (1999, p. 222), para se utilizar eficientemente esses instrumentos deve-se seguir os seguintes passos:

1. Determinação dos dados a serem coletados;

2. Determinação do instrumento e forma de aplicação;

3. Redação do rascunho;

4. Revisão e pré-teste;

5. Redação final.

Todos os passos foram seguidos. Primeiramente, decidiu-se, por meio de dados qualitativos e quantitativos, investigar a percepção dos consumidores em relação à questão a ser analisada, com auxílio de dois instrumentos: uma entrevista pessoal e um questionário estruturado.

O passo seguinte foi decidir quanto à forma de aplicação dos dois instrumentos. Decidiu-se por realizar a entrevista com o engenheiro de operações, com o fim de conseguir opiniões e informações referentes à gestão da empresa, na forma de uma entrevista estruturada, ou seja, com um roteiro organizado previamente. As perguntas foram elaboradas com base nos objetivos específicos deste trabalho.

Quanto ao questionário estruturado, escolheu-se aplicá-lo aos clientes e consumidores, para descrever suas percepções acerca da imagem e das práticas ambientais da empresa e como isso influencia em suas preferências e seus hábitos. Esse questionário foi desenvolvido com perguntas fechadas de múltipla escolha. 


\subsection{Procedimentos de coleta de dados}

Depois de definidos os instrumentos de pesquisa e sua forma de aplicação, foi então realizada a entrevista pessoal com o engenheiro de operações, o qual contou com a ajuda do Diretor de Marketing em algumas perguntas.

Realizada a entrevista, começou-se então a coleta dos dados junto aos clientes do shopping aplicando-se o questionário elaborado com perguntas fechadas de forma a dar subsídio ao estudo de caso. Foi decidido que este fosse enviado por meio eletrônico acompanhado de uma carta explicação contendo as instruções para envio das respostas.

O questionário eletrônico, segundo Silva et al (1997), é aquele que utiliza o meio eletrônico para ser aplicado. $\mathrm{O}$ autor cita ainda duas formas de se implementar esse tipo de pesquisa:

- Envio do questionário por e-mail, pelo qual o participante responde a mensagem com as questões preenchidas;

- Disponibilização do questionário em uma página da Internet, em que o participante é informado sobre o endereço da página do questionário na Internet, por e-mail ou anúncio eletrônico. Neste caso, o respondente pode participar sem se identificar.

Optou-se pelo uso da segunda forma, uma vez que, ao clicar no botão "enviar" o participante envia as respostas para o responsável pela pesquisa, o que proporciona uma tabulação mais ágil e menor probabilidade de erros.

Evans e Mathur (2005) citam como principais vantagens do questionário eletrônico: a agilidade na aplicação das perguntas e na tabulação dos resultados; a facilidade de uso de amostras maiores; o baixo custo de implementação e a exigência de resposta completa. Para o participante, segundo o autor, o questionário eletrônico possibilita rapidez no preenchimento e facilidade de leitura. Já para o pesquisador, o autor destacou o controle sobre o preenchimento incorreto das questões, tendo em vista que o participante só avança para o item seguinte se a questão foi respondida corretamente. 
Souza (2000), ao tratar do assunto, destaca como vantagem o fato das pessoas, ao responderem as questões diante do computador, poderem fazê-lo no momento de sua preferência. Isso também faz com que o participante não se sinta inibido e responda com honestidade.

Antes da aplicação, o questionário foi validado por meio de pré-testes realizados pessoalmente com vinte consumidores. Após os ajustes necessários, o questionário foi aplicado de 20 de setembro a 03 de outubro de 2010, em uma amostra acidental, enviando-se aleatoriamente, por listas de e-mail e sites de relacionamento, um formulário contendo três questões referentes ao perfil do respondente e quatro em relação à sua atitude e opinião no que concerne à gestão ambiental do Pátio Brasil Shopping. De acordo com Martins (2005), a amostragem acidental consiste em uma amostra formada pelos elementos que vão aparecendo, que são possíveis de se obter, e é normalmente utilizada em pesquisas de opinião, em que os entrevistados são acidentalmente escolhidos. Quanto às listas de e-mail, estas foram formadas por conhecidos e parentes moradores de várias regiões do Distrito Federal e de seu entorno, para que a pesquisa alcançasse diversas faixas etárias e classes sociais.

\subsection{Procedimentos de análise de dados}

A análise de conteúdo de acordo com a metodologia de Bardin (2002) foi escolhida para se estudar os dados obtidos na entrevista. Em relação ao questionário aplicado aos consumidores foram realizadas análises estatísticas utilizando-se o software Microsoft Excel 2008 for Mac, pelo qual foram tabulados os dados e desenvolvidos os gráficos e as tabelas.

$\mathrm{Na}$ análise do conteúdo da entrevista foram empregadas técnicas de análise de comunicações, com o propósito de se obter indicadores que permitissem conhecer as variáveis inferidas das entrevistas, conforme prescreve Bardin (2002). Nesta análise foram empregadas técnicas jornalísticas com a transcrição de trechos de entrevistas, conforme propõe Vergara (2005). 
O processo de análise dos dados ocorreu em três momentos:

No primeiro, os dados foram organizados, e as entrevistas transcritas, ocasionando entre o conteúdo das entrevistas e o referencial teórico estudado uma primeira aproximação.

Em seguida, as respostas dadas pelo entrevistado foram classificadas em categorias ou classes. A partir daí, as opiniões dos consumidores puderam ser comparadas com as informações prestadas pelo engenheiro de operações do shopping.

No último momento, os dados foram confrontados e analisados, para se verificar se é verdadeira a questão proposta por este trabalho, ou seja, se a gestão com práticas sustentáveis influencia na imagem da organização, e até que ponto essa influência pode gerar vantagens diante da concorrência. 


\section{RESULTADOS E DISCUSSÃO}

Para a apresentação dos resultados das duas abordagens, foram aplicados, tanto na pesquisa qualitativa como na quantitativa, os procedimentos exigidos pela análise de conteúdo de acordo com a metodologia de Bardin (2002).

A análise de conteúdo consiste em uma técnica de investigação que descreve o conteúdo da comunicação de maneira objetiva, sistemática e quantitativa. Para ser objetiva, definem-se precisamente as categorias de análise, de maneira que outros pesquisadores possam utilizar a mesma descrição e obtenham resultados semelhantes. Para que seja sistemática, a integridade do conteúdo deve ser analisada comparando-se às categorias de análise. E, finalmente, para ser quantitativa, a análise precisa captar informações objetivas relacionadas à frequência de ocorrência das características do conteúdo (BERELSON, 1952).

\subsection{Análise de Conteúdo da entrevista}

As bases da análise de conteúdo, no entendimento de Bardin (2002) são a preparação do material, a inferência e a interpretação. Diante dessa afirmação, a entrevista realizada com o engenheiro de operações foi registrada por meio de gravação em áudio e, em seguida, transcrita na íntegra para leitura flutuante e preparação do material. A gravação foi autorizada pelo entrevistado.

Ainda na fase de preparação, seguindo a metodologia descrita por Bardin (2002), adotou-se a técnica da análise temática ou categorial para o tratamento dos dados. O texto foi desmembrado em diferentes núcleos de sentido para, depois, serem agrupados em classes ou categorias. Após a leitura do conteúdo da entrevista, foram observadas as seguintes classes: a relação do Pátio Brasil com a Sonae Sierra; a metodologia aplicada na implementação do SGA adotado pela organização; a participação da população interna; a influência do SGA na imagem da organização; as vantagens proporcionadas pela adoção da certificação ISO 14001; e a influência das práticas ambientais na cultura dos consumidores. 
Com base nas respostas do entrevistado, foi feito um resumo das ideias, as quais foram organizadas de acordo com a categoria adequada. Senão, veja-se:

1. Relação do Pátio Brasil com a Sonae Sierra

A Sonae Sierra é uma empresa portuguesa que administra shoppings, a qual tem como sócia, em alguns empreendimentos, a Sonae Sierra Brasil. Esta almeja ser a melhor especialista sustentável em shopping centers no país. O Pátio Brasil Shopping é administrado pela Sonae Sierra Brasil, cujo escritório central marca auditorias para controle das práticas de gestão ambiental de suas empresas seguindo as normas da ISO 14001. De acordo com o entrevistado, a administração da Sonae Sierra só gera vantagens ao shopping no que tange à imagem corporativa, pelo fato da mesma ser conhecida como uma empresa que investe alto em sustentabilidade. Não gera outros benefícios, visto que a Sonae possui pouco poder de voto no Pátio Brasil. As diretrizes de gerenciamento da empresa são originárias da Sonae Sierra Brasil, mas de acordo com a empresa portuguesa.

2. Metodologia aplicada na implementação do SGA adotado pela organização

Para alcançar a certificação ISO 14001, o shopping precisou adequar a questão de geração de resíduos às normas, e decidir quais empresas escolheria como parceiras, verificando se essas empresas possuíam a documentação ambiental em dia, e exigindo que essas empresas adequassem a geração e descarga de seus resíduos.

O SGA levou cerca de dois anos para ser desenvolvido na empresa e conta com auditorias internas anuais com o fim de avaliar e identificar erros.

Para mensurar os resultados obtidos com a implementação do sistema, as empresas terceirizadas informam ao shopping a quantidade e o peso dos resíduos gerados, e são elaborados gráficos mensais para análise do consumo de água e energia.

Dentre as práticas ambientais adotadas pelo shopping, destacam-se o controle de emissão de gases dos caminhões, a coleta seletiva, o Ecoponto realizado mensalmente - e o Ecocartoon. Em relação aos resíduos, duas vezes ao dia os funcionários responsáveis pela limpeza passam pelas lojas 
com um carrinho coletando papelão, plásticos e lâmpadas. Estas são enviadas para a empresa Brasil Recicle. O papelão e os plásticos vão para a empresa Trash Ambiental que possui um contrato com a Capital Reciclagens onde o material é reciclado.

3. Participação da população interna

Segundo o entrevistado, os colaboradores lojistas são bem conscientizados e participam bastante das práticas ambientais. Há treinamentos mensais que procuram educar ambientalmente os funcionários e lojistas.

4. Influência do SGA na imagem da organização

Segundo o entrevistado, o envolvimento com ações de meio ambiente proporcionou ao shopping o reconhecimento da comunidade contribuindo positivamente para a imagem corporativa e para a construção de um posicionamento diferenciado perante a concorrência. No entanto, ainda não foram adotadas medidas para avaliação quanto ao aspecto de retorno financeiro ou de negócios.

5. Vantagens proporcionadas pela adoção da certificação ISO 14001

Além do reconhecimento da sociedade, a adoção das normas ambientais tem proporcionado diminuição do consumo de água e energia.

6. Influência das práticas ambientais na cultura dos consumidores

A divulgação dos programas é feita apenas por mídia espontânea, ou seja, os consumidores são informados das ações ambientais por outros consumidores, ou por notícias que surgem em jornais. Não obstante, bastantes consumidores participam dos programas, parabenizam e agradecem ao shopping. No entendimento do entrevistado, isso acaba influenciando os hábitos dos participantes, principalmente, os mais jovens.

$\mathrm{Na}$ fase posterior, após o tratamento dos dados, estes foram submetidos à interpretação e análise reflexiva comparando-se o conteúdo da entrevista com os dados obtidos na pesquisa quantitativa, a fim de servirem de base para a discussão dos resultados. 


\subsection{Análise dos dados quantitativos}

Para a organização dos dados coletados na pesquisa quantitativa, optou-se por, inicialmente, qualificar os participantes da pesquisa, identificando-os pela faixa etária e pelo grau de escolaridade. A tabela 1 demonstra que a maior parte das pessoas que participaram da pesquisa encontra-se na faixa de 25 a 34 anos de idade com 35,9\% dos entrevistados. A faixa de 35 a 49 anos de idade foi a segunda classe mais representativa com $31,5 \%$ do grupo participante.

Tabela 1: Faixa etária dos participantes

\begin{tabular}{lrr}
\hline Faixa Etária & Frequência & Percentual \\
\hline 18 a 24 anos & 114 & 26,6 \\
25 a 34 anos & 154 & 35,9 \\
35 a 49 anos & 135 & 31,5 \\
50 a 60 anos & 16 & 3,7 \\
Mais de 60 anos & 10 & 2,3 \\
\hline Total & 429 & 100,0 \\
\hline
\end{tabular}

Fonte: Elaborada pelo autor

É importante também conhecer o grau de instrução dos participantes. A tabela 2 mostra que mais da metade do grupo (50,3\%) possui ensino médio completo ou curso de nível superior incompleto. Pode-se perceber também que apenas $9,1 \%$ dos entrevistados não possuem ensino fundamental completo.

Tabela 2: Grau de instrução dos participantes

\begin{tabular}{lrr}
\hline Grau de Instrução & Frequência & Percentual \\
\hline Fundamental incompleto & 39 & 9,1 \\
Médio incompleto ou Fund. completo & 53 & 12,4 \\
Superior incompleto ou Médio completo & 216 & 50,3 \\
Pós-Grad. ou Superior completo & 121 & 28,2 \\
\hline Total & 429 & 100,0 \\
\hline
\end{tabular}

Fonte: Elaborada pelo autor 
Após a identificação do grupo participante do estudo, foi feita a análise dos dados comparando as opiniões de acordo com os perfis dos entrevistados. A tabela 3 foi elaborada com o fim de facilitar a análise das respostas considerando as idades. Vale destacar que a primeira pergunta do questionário, a qual pretendeu verificar se o participante já visitou o Pátio Brasil ou não, foi respondida positivamente por todos os respondentes.

Tabela 3: Questionário - faixa etária

\begin{tabular}{|c|c|c|c|c|c|c|c|}
\hline \multirow{2}{*}{\multicolumn{2}{|c|}{ Questões }} & \multicolumn{5}{|c|}{ Faixa Etária } & \multirow{3}{*}{$\begin{array}{r}\text { Totais } \\
35,0\end{array}$} \\
\hline & & \multirow{2}{*}{$\begin{array}{c}\begin{array}{c}18 \text { a } 24 \\
\text { anos }\end{array} \\
22,8\end{array}$} & \multirow{2}{*}{$\begin{array}{c}\begin{array}{c}25 \text { a } 34 \\
\text { anos }\end{array} \\
43,5\end{array}$} & \multirow{2}{*}{$\begin{array}{c}\begin{array}{c}35 \text { a } 49 \\
\text { anos }\end{array} \\
33,3\end{array}$} & \multirow{2}{*}{$\begin{array}{c}50 \text { a } 60 \\
\text { anos }\end{array}$} & \multirow{2}{*}{$\begin{array}{l}\begin{array}{r}\text { Mais } \\
\text { de } 60 \\
\text { anos }\end{array} \\
50,0\end{array}$} & \\
\hline \multirow{3}{*}{$\begin{array}{l}\text { Você conhece as ações } \\
\text { ambientais realizadas pelo } \\
\text { Pátio Brasil? }\end{array}$} & Não conheço & & & & & & \\
\hline & $\begin{array}{c}\text { Conheço } \\
\text { apenas uma }\end{array}$ & 46,5 & 27,9 & 41,5 & 37,5 & 40,0 & 37,8 \\
\hline & $\begin{array}{c}\text { Conheço } \\
\text { duas ou mais }\end{array}$ & 30,7 & 28,6 & 25,2 & 18,8 & 10,0 & 27,3 \\
\hline \multirow{3}{*}{$\begin{array}{l}\text { Quando você efetua uma } \\
\text { compra, dá preferência a } \\
\text { produtos sustentáveis? }\end{array}$} & Nunca & 8,8 & 7,1 & 19,3 & 31,3 & 50,0 & 13,3 \\
\hline & Às vezes & 81,6 & 87,7 & 77,8 & 56,3 & 30,0 & 80,4 \\
\hline & Sempre & 9,7 & 5,2 & 3,0 & 12,5 & 20,0 & 6,3 \\
\hline \multirow{3}{*}{$\begin{array}{l}\text { O fato de uma empresa ter a } \\
\text { certificação ISO } 14001 \\
\text { influencia em sua preferência? }\end{array}$} & Nunca & 21,9 & 36,4 & 51,1 & 56,3 & 50,0 & 38,2 \\
\hline & Às vezes & 63,2 & 52,0 & 45,2 & 37,2 & 50,0 & 52,2 \\
\hline & Sempre & 14,9 & 11,7 & 3,7 & 6,3 & 0,0 & 9,6 \\
\hline \multirow{2}{*}{$\begin{array}{l}\text { As práticas ambientais de } \\
\text { empresas como o Pátio Brasil } \\
\text { já Ihe influenciaram mudando } \\
\text { seus princípios ou costumes? }\end{array}$} & Sim & 74,6 & 55,8 & 48,9 & 31,3 & 30,0 & 57,1 \\
\hline & Não & 25,4 & 44,2 & 51,1 & 68,8 & 70,0 & 42,9 \\
\hline
\end{tabular}

Fonte: Elaborada pelo autor

Pode-se concluir que a divulgação das práticas ambientais do Pátio Brasil citadas pelo engenheiro de operações na entrevista pessoal poderia ser mais eficaz, visto que apenas $27 \%$ das pessoas responderam que conhecem duas ou mais ações ambientais promovidas pela empresa. A figura 2 facilita essa visualização. 


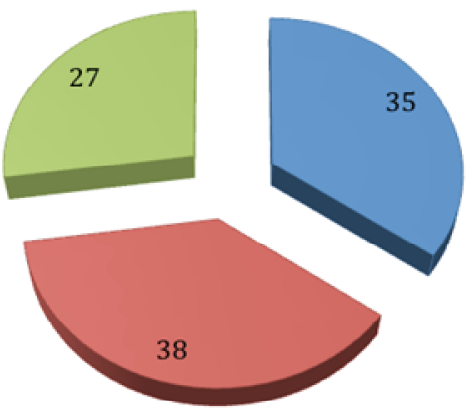

$\square$ Não conheço

$\square$ Conheço apenas uma

$\square$ Conheço duas ou mais

Figura 2: Conhecimento das ações ambientais - consumidores Fonte: Elaborada pelo autor

A tabela 4 separa as respostas envolvendo a escolaridade dos participantes:

Tabela 4: Questionário - grau de instrução

\begin{tabular}{|c|c|c|c|c|c|c|}
\hline \multirow{2}{*}{\multicolumn{2}{|c|}{ Questões }} & \multicolumn{4}{|c|}{ Grau de Instrução } & \multirow[b]{2}{*}{ Totais } \\
\hline & & Fundam. & $\begin{array}{c}\text { Médio } \\
\text { incomp. }\end{array}$ & $\begin{array}{l}\text { Superior } \\
\text { incomp. }\end{array}$ & $\begin{array}{l}\text { Pós ou } \\
\text { Superior }\end{array}$ & \\
\hline \multirow{3}{*}{$\begin{array}{l}\text { Você conhece as ações } \\
\text { ambientais realizadas } \\
\text { pelo Pátio Brasil? }\end{array}$} & Não conheço & 51,3 & 47,2 & 31,0 & 31,4 & 35,0 \\
\hline & $\begin{array}{c}\text { Conheço } \\
\text { apenas uma }\end{array}$ & 33,3 & 39,6 & 38,4 & 37,2 & 37,8 \\
\hline & $\begin{array}{c}\text { Conheço } \\
\text { duas ou mais }\end{array}$ & 15,4 & 13,2 & 30,6 & 31,4 & 27,3 \\
\hline \multirow{3}{*}{$\begin{array}{l}\text { Quando você efetua } \\
\text { uma compra, dá } \\
\text { preferência a produtos } \\
\text { sustentáveis? }\end{array}$} & Nunca & 30,8 & 24,5 & 12,0 & 5,0 & 13,3 \\
\hline & Às vezes & 64,1 & 69,8 & 81,5 & 88,4 & 80,4 \\
\hline & Sempre & 5,1 & 5,7 & 6,5 & 6,6 & 6,3 \\
\hline \multirow{3}{*}{$\begin{array}{l}\text { O fato de uma empresa } \\
\text { ter a certificação ISO } \\
14001 \text { influencia em sua } \\
\text { preferência? }\end{array}$} & Nunca & 46,2 & 26,4 & 38,4 & 40,5 & 38,2 \\
\hline & Às vezes & 51,3 & 58,5 & 50,5 & 52,9 & 52,2 \\
\hline & Sempre & 2,6 & 15,1 & 11,1 & 6,6 & 9,6 \\
\hline \multirow{2}{*}{$\begin{array}{l}\text { As práticas ambientais } \\
\text { de empresas como o } \\
\text { Pátio Brasil já lhe } \\
\text { influenciaram mudando } \\
\text { seus princípios ou } \\
\text { costumes? }\end{array}$} & Sim & 61,5 & 43,4 & 54,2 & 66,9 & 57,1 \\
\hline & Não & 38,5 & 56,6 & 45,8 & 33,1 & 42,9 \\
\hline
\end{tabular}

Fonte: Elaborada pelo autor 
Quando se trata da análise relacionada à preferência do consumidor ao comprar um produto sustentável, verifica-se que, enquanto apenas $9 \%$ dos participantes de 18 a 24 anos responderam que nunca dão preferência a esses produtos, 19\% dos que possuem de 35 a 49 anos deram a mesma resposta. Percebe-se também que o índice dos que responderam que sempre preferem os produtos sustentáveis ao efetuar uma compra é três vezes maior para a primeira faixa etária em relação aos que possuem de 35 a 49 anos, como mostra a figura 3.

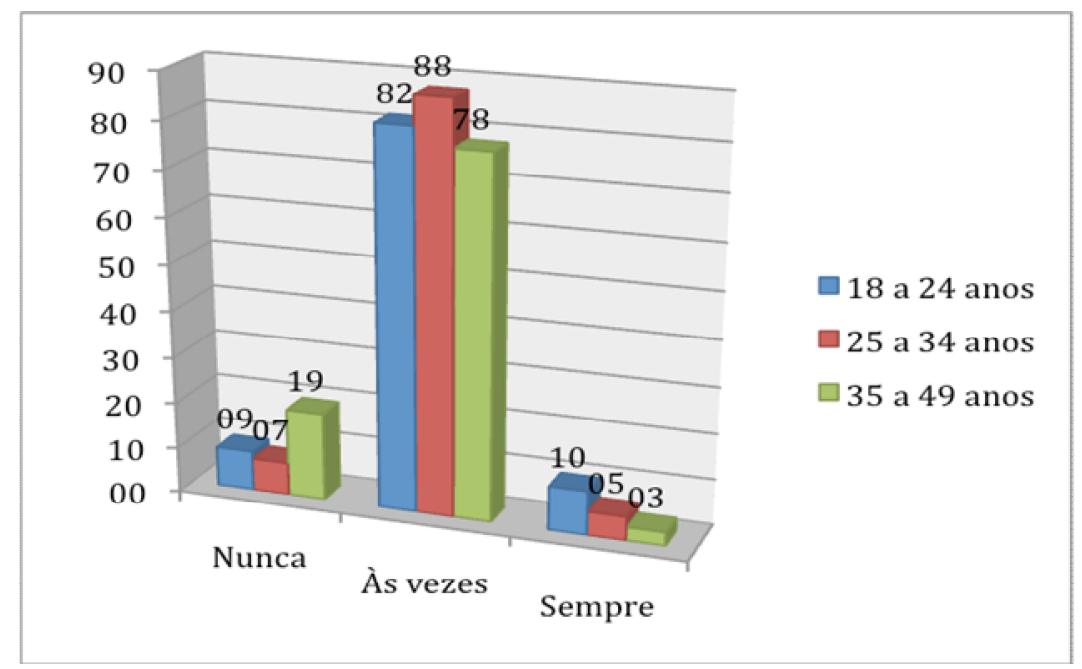

Figura 3: Preferência dos consumidores - faixa etária Fonte: Elaborada pelo autor

Evolução semelhante encontra-se quando se analisa considerando a escolaridade dos participantes. Nota-se que quanto maior o grau de instrução, maior a preocupação em dar preferência a produtos ecologicamente corretos. A figura 4 apresenta esses dados.

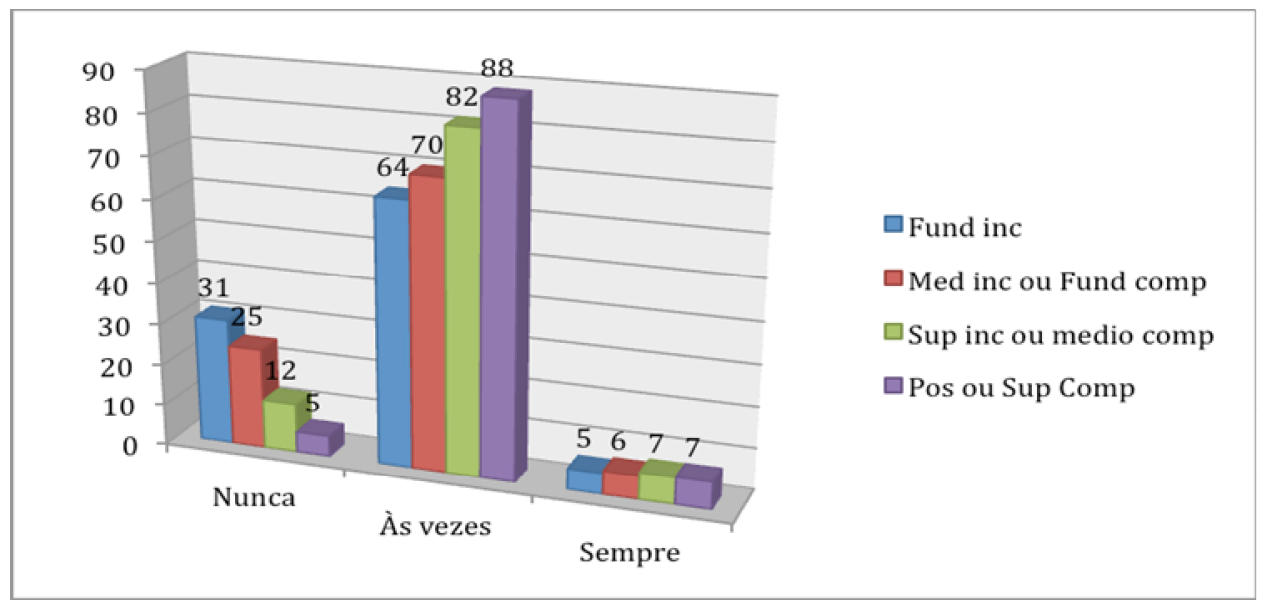

Figura 4: Preferência dos consumidores - grau de instrução Fonte: Elaborada pelo autor 
A próxima análise estudou a questão se a adoção do certificado ISO 14001 influencia a escolha do consumidor. A figura 5 abaixo mostra que a maioria esmagadora do grupo de 18 a 24 anos (78\%, considerando 63\% mais 15\%) respondeu que o certificado os influencia sempre ou às vezes. No entanto, a maioria dos que possuem 50 a 60 anos (56\%) afirmou que nunca se preocupa se a empresa possui ou não a certificação ISO 14001.

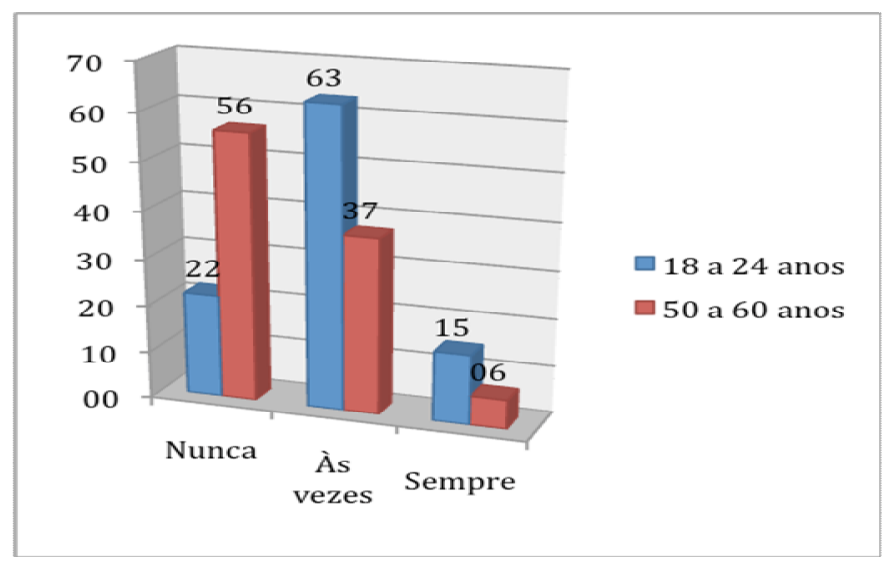

Figura 5: Influência da ISO 14001 - faixa etária Fonte: Elaborada pelo autor

No que concerne a análise considerando a escolaridade dos participantes, verifica-se que a certificação ISO 14001, de acordo com as respostas, influencia mais as pessoas com menor grau de instrução, consoante a figura 6. Isso se deve ao fato dessa categoria ser composta em sua maioria pelos mais jovens, os quais, como pode-se concluir pela análise anterior, são mais influenciados pelas práticas sustentáveis.

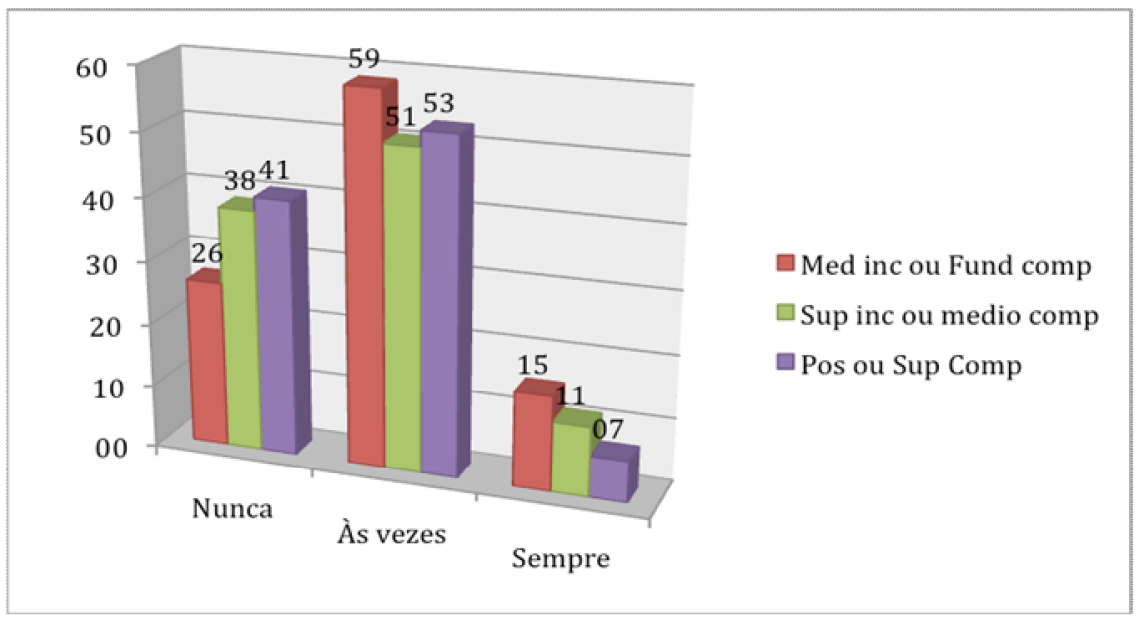

Figura 6: Influência da ISO 14001 - grau de instrução Fonte: Elaborada pelo autor 
Através da última questão respondida, pode-se analisar se as práticas ambientais do Pátio Brasil têm influenciado os costumes dos consumidores. A figura 7 mostra uma análise bem otimista, uma vez que quanto menor a idade, maior o índice dos que responderam positivamente, isto é, que já mudaram seus princípios ou costumes incentivados por uma ação ambiental da empresa.

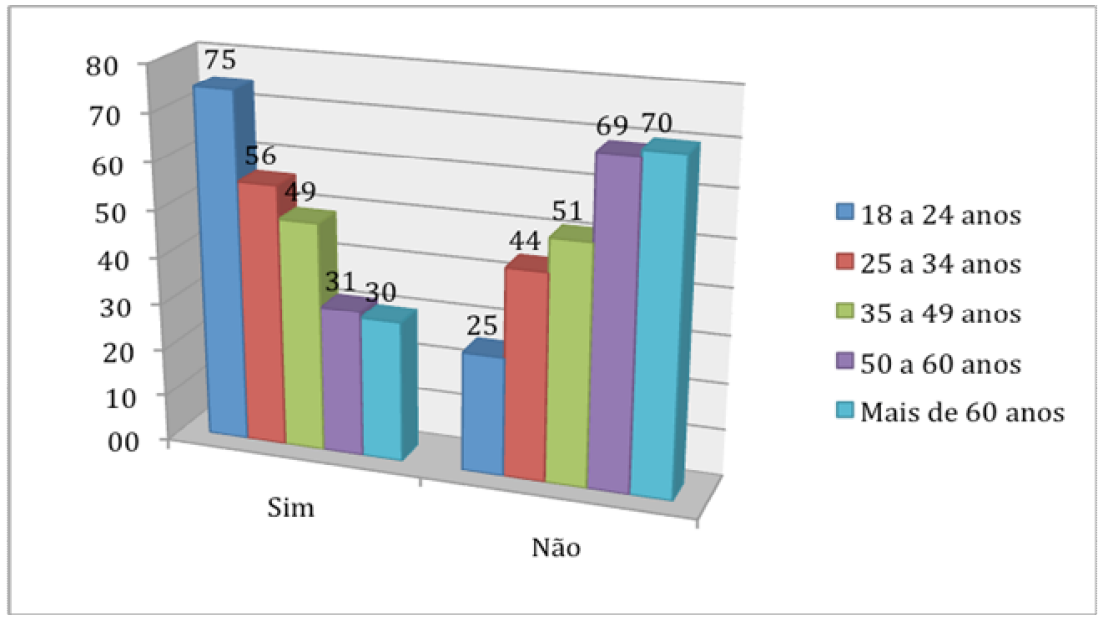

Figura 7: Influência das práticas ambientais - faixa etária Fonte: Elaborada pelo autor

Já em relação à escolaridade do grupo, o resultado foi diferente da questão anterior, que trata da certificação ISO 14001, pois quanto maior o grau de instrução, maior o número dos que responderam que as ações do shopping já influenciaram seus costumes, o que pode ser analisado pela figura 8.

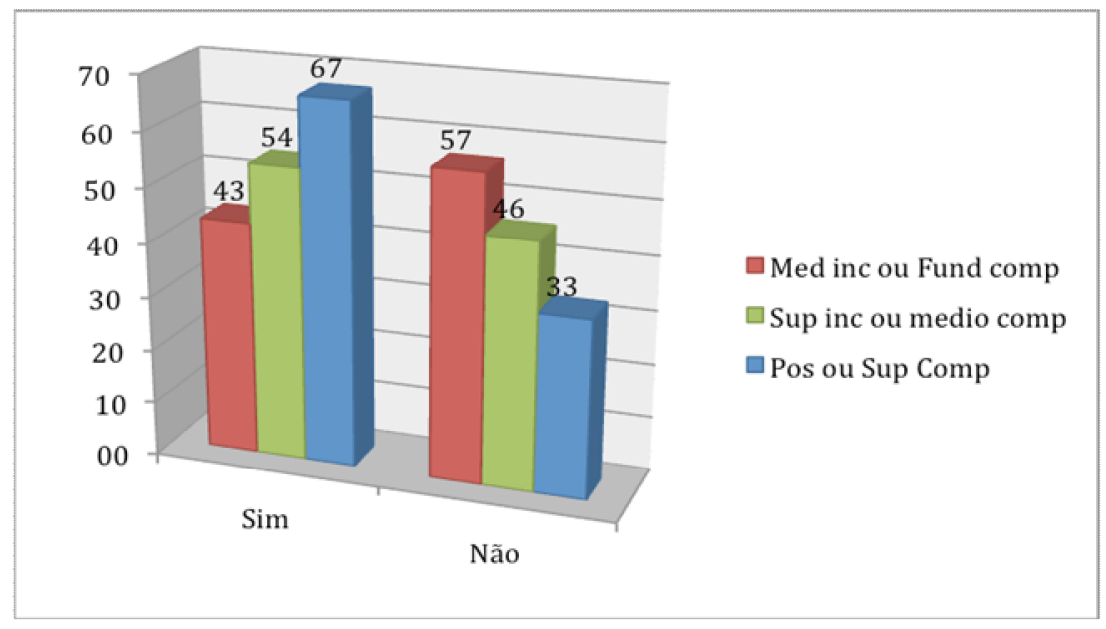

Figura 8: Influência das práticas ambientais - grau de instrução Fonte: Elaborada pelo autor 


\section{CONSIDERAÇÕES FINAIS}

Buscou-se, neste trabalho, analisar a influência da gestão ambiental na imagem das organizações. Como será exposto neste capítulo, a certificação ISO 14001 não tem gerado vantagens significativas ao Pátio Brasil Shopping. O motivo de uma empresa adotar um sistema de gestão ambiental e não usufruir de vantagens relevantes pode estar associado à cultura da sociedade na qual essa empresa está inserida. Os estudos citados anteriormente da UNEP (2001) e do Instituto Ethos (2003) chegaram à conclusão de que os benefícios originários da gestão ambiental estão associados, nos países desenvolvidos, à reputação da empresa e, nos países emergentes, à redução de custos e ampliação a novos mercados. Esse pensamento ganha força quando se compara este trabalho com as pesquisas realizadas pela associação internacional World Business Council for Sustainable Development, as quais apontam diversos exemplos de empresas que obtêm vantagens financeiras resultantes da administração sustentável (WBCSD,1997).

Diante dos resultados do presente estudo é possível declarar que os objetivos foram alcançados. A seguir estão listadas as conclusões referentes a cada objetivo específico proposto:

- Descrever como a adoção do certificado ISO 14001 promove vantagens para a organização;

A maioria dos entrevistados respondeu que às vezes a ISO 14001 influencia em suas decisões. A porcentagem dos que se preocupam com a sustentabilidade aumentou para os participantes mais jovens. Contudo, podese perceber que, ainda que a empresa adote diversas ações e práticas ambientais, a pesquisa demonstrou que as mesmas são pouco divulgadas, pois 35\% dos respondentes afirmaram não conhecer nenhuma prática. 
Em relação à vantagem econômica, de acordo com a entrevista, a única vantagem gerada pela implantação do SGA foi a economia no consumo de água e energia.

- Verificar como as práticas sustentáveis interferem na imagem de um shopping center;

Os resultados da pesquisa apontam que o nível de influência na imagem do shopping não é significativo diante das opiniões dos consumidores, visto que apenas $9,6 \%$ dos entrevistados disseram que sempre dão preferência a empresas que possuem a certificação ISO 14001.

- Identificar de que maneira a gestão ambiental influencia o público consumidor. Os resultados mostram que $75 \%$ dos participantes com idade inferior a 25 anos afirmaram que já mudaram alguns hábitos influenciados pelas ações ambientais promovidas pelo shopping. Já entre os entrevistados de 50 a 60 anos de idade, $69 \%$ disseram que as práticas sustentáveis nunca os influenciaram. Conclui-se que a geração mais jovem tem se mostrado mais aberta à conscientização ambiental, e essa conclusão foi dita na entrevista pessoal.

Nota-se que a gestão ambiental influencia positivamente a imagem corporativa da organização estudada, mas não o faz a ponto de gerar-lhe vantagens explícitas e significativas, situação que pode variar no futuro. Verifica-se essa afirmação ao se considerar nos resultados alguns fatores que favorecem a confiança em boas perspectivas futuras no que tange à valorização das questões ambientais. Esse argumento apoia-se na seguinte possibilidade: se, na pesquisa quantitativa efetuada, fossem consideradas somente as respostas dadas por participantes com menos de 35 anos de idade, o resultado seria mais prestigioso no que concerne ao nível de influência da gestão ambiental, uma vez que, em algumas questões, as respostas a favor da influência desse tipo de gestão são inversamente proporcionais à idade dos respondentes, isto é, quanto menor a idade, maiores as preocupações com as práticas sustentáveis. 
Dos resultados da pesquisa relacionados ao grau de instrução, também se podem inferir boas perspectivas para o futuro da gestão ambiental, em virtude do aumento do tempo em que as pessoas têm se dedicado à educação (CZAPSKI, 1998). Existem estudos que associam as preocupações ambientais das organizações à educação ambiental. Senão, veja-se:

Entre as razões pelas quais as empresas se preocupam em adotar a gestão ambiental, Souza (2002) cita as mudanças do nível de conhecimento, já mencionada anteriormente neste trabalho, proporcionadas pelas crescentes descobertas sobre as causas e os efeitos dos danos ambientais. Pode-se considerar que, quanto mais uma pessoa estuda, mais tem contato com temas ambientais, já que a questão ambiental tem estado cada vez mais presente no âmbito acadêmico, fato constatado ao se analisar a crescente criação de leis e projetos que determinam e regulamentam a educação ambiental (CZAPSKI,1998). Diante disso, todos os níveis de educação desempenham papel fundamental na conscientização ecológica, quando cumpridos consoante aos parâmetros curriculares nacionais (BRASIL,1997) e às normas estabelecidas na Política Nacional de Educação Ambiental (BRASIL, 1999).

Conclui-se, portanto, que essa teoria defendida por Souza (2002) tem fundamento na pesquisa aplicada ao público frequentador do shopping, uma vez que $67 \%$ dos respondentes que possuem nível superior completo afirmaram já terem mudado seus costumes influenciados por práticas sustentáveis de gestão, ao passo que $57 \%$ dos de escolaridade fundamental ou ensino médio incompleto responderam que nunca o fizeram. Quanto à tomada de decisão na hora de comprar um produto, $31 \%$ dos entrevistados que não completaram o ensino fundamental responderam que nunca dão preferência a produtos sustentáveis. Já entre os que já completaram o ensino médio ou possuem nível superior incompleto, 12\% deram essa resposta. Esse número cai para apenas $5 \%$ entre os entrevistados que possuem ensino superior completo. 


\section{REFERÊNCIAS}

ABNT - Associação Brasileira de Normas Técnicas. Rumo à certificação ISO 14000. São Paulo: ABNT, 1996.

ABNT. NBR ISO 14001 - Sistemas da Gestão Ambiental - Requisitos com orientações para uso. Rio de Janeiro: ABNT, 2004.

BARDIN, Laurence. Análise de conteúdo. Lisboa: Edições 70, 2002.

BERELSON, Bernard. Content Analysis in Communication Research. Glencoe, III: Free Press, 1952.

BRASIL. Ministério do Meio Ambiente, dos Recursos Hídricos e da Amazônia Legal. Programa Nacional de Educação Ambiental. Brasília, 1997.

BRASIL. Ministério da Educação. Secretaria de Educação Média e Tecnológica. Parâmetros Curriculares Nacionais: ensino médio: bases legais. Brasília, 1999.

CALLENBACH, E., CAPRA, F., GOLDMAN, L., LUTZ, R., MARBURG, S., Gerenciamento Ecológico. São Paulo: Editora Cultrix,, 1993.

CERQUEIRA, J. P.; MARTINS, M. C. Auditorias de Sistemas de Gestão. Rio de Janeiro: Ed. Qualitymark, 2005.

CHIELE, Caroline. Sistema aprimorado de gestão ambiental: um estudo de caso na empresa Tritec Motors Ltda. Porto Alegre: UFRS, 2003.

CZAPSKI, Silvia. A implantação da Educação Ambiental na Brasil - Secretaria do Meio Ambiente, Brasília. 1a ed. 1998.

CZINKOTA, Michael $R$. et al. Marketing: as melhores práticas. Porto Alegre: Bookman, 2001.

DYLLICK, et al. Guia da Série de Normas ISO 14001: Sistema de Gestão Ambiental. Tradução de Beate Frank. Blumenau: Edifurb, 2000.

DONAIRE, Denis. A internalização da gestão ambiental na empresa. Revista de 
Administração USP, São Paulo, v.31, n.1, p. 44-51, jan./mar.1996.

DONAIRE, Denis . Gestão ambiental na empresa. São Paulo: Ed. Atlas, 2 ed., 1999.

EPELBAUM, Michel. A influência da gestão ambiental na competitividade e sucesso empresarial. 2004. 190p. Dissertação (Mestrado em Engenharia da Produção) Escola Politécnica da Universidade de São Paulo.

ETHOS. Criando valor: o business case para sustentabilidade em mercados emergentes. 2003. Disponível em <http://ethos.org.br>, acesso em 29 de março de 2010 .

EVANS, J. R.; MATHUR, A. The Value of Online Surveys. Internet Research, v. 15, n. 2, 2005, p. 195-219.

GODOY, A. S. Introdução à pesquisa qualitativa e suas possibilidades. In: Revista de Administração de Empresas. São Paulo:v.35, n.2, p. 57-63, abril 1995.

HOJDA, Ricardo Gross. Gestão Ambiental é vantagem competitiva. In GAZETA MERCANTIL, 13/05/98.

KOTLER, Philip. Administração de Marketing. São Paulo: Prentice-Hall, 2000.

KRAEMER, Maria Elisabeth Pereira. A busca de estratégias competitivas através de gestão ambiental. Disponível em <http://www.abdir.com.br/doutrina/ver.asp?art_id=\&categoria= Contabilidade > Acesso em: 28 de março de 2010

MACEDO, Kátia Barbosa; OLIVEIRA, Alberto de. A gestão ambiental nas organizações como nova variável estratégica. RPOT - Revista de Psicologia: Organizações e trabalho. Vol. 5, N 1, p. 129 - 158, janeiro - junho. 2005.

MARTINS, Gilberto de Andrade. Estatística geral e aplicada. São Paulo: Editora Atlas, 2005. 3a Edição.

MATTAR, Fauze Najib. Pesquisa de Marketing: metodologia e planejamento. São Paulo: Editora Atlas, 1999. 337 p., Volume 1, 5a edição.

MINAYO, Maria Cecília de Souza. O desafio do Conhecimento: pesquisa qualitativa em saúde. São Paulo - Rio de Janeiro: Hucitec - Abrasco. 1996. 
MOURA JÚNIOR, Armando Noé carvalho; ROQUE, Vânia Ferreira. Gerenciamento Ecológico Gerando Vantagens Competitivas para as empresas. Florianópolis: 1997.

NEVES, J. L. Pesquisa qualitativa: características, usos e possibilidades. Caderno de Pesquisas em Administração, São Paulo, v.1, n.3, 2.sem.,1996, p. 1-5.

NOVAES, W. Mercado para quem não polui. Visão, 1991.

PÁTIO BRASIL SHOPPING. Meio Ambiente. Disponível em: <http://www.patiobrasil.com.br>. Acesso em: 10 de abril de 2010.

PINHO, J. B. O poder das Marcas. São Paulo: Summus, 1996. Relatório de Atividades 2000/2001. Centro de Design do Paraná.

RAYNAUT, Claude; ZANONI, Magda. La Construction de l'interdiciplinarité en Formation integrée de l'environnement et du Développement. Paris: Unesco. 1993.

ROSSI, Paula. Adoção Da Gestão Ambiental Para Otimização Da Imagem Da Marca: Hospital Dia E Maternidade Unimed BH: Um Estudo De Caso. 2008. Disponível em <http://artigos.netsaber.com.br/resumo_artigo_5776/artigo_sobre_ adocao_da_gestao_ambiental_para_otimizacao_da_imagem_da_marca:_hospital_di a_e_maternidade_unimed_bh:_um_estudo_de_caso1>, acesso em 29 de março de 2010 .

SEMENIK, Richard J; BAMOSSY, Gary J. Princípios de Marketing: uma perspectiva global. São Paulo: Makron Books, 1996.

SILVA, S. M. et al. O Uso do Questionário Eletrônico na Pesquisa Acadêmica: Um Caso de Uso na Escola Politécnica da Universidade de São Paulo, II Semead Seminários em Administração do Programa de Pós-Graduação em Administração da FEA/USP, 1997. p.408-421.

SOUZA, Ana Paula. Diga-me via Internet: site oferece pesquisas de campo online. Meio \& Mensagem, São Paulo, ano 22, u. 920, p. 36, ago. 2000.

SOUZA, R. S. A evolução e condicionantes da gestão ambiental nas empresas. REAd - Edição Especial 30. Universidade Federal de Santa Maria: UFSM. 2002

TAVARES, Mauro Calixta. A força da marca - Como construir e manter marcas fortes. São Paulo: Harbra, 1998. 
UNEP, Sustainability. Buried treasure: uncovering the business case for corporate sustainability. 2001. Disponível em <http://www.sustainability.com>, acesso em 28 de março de 2010.

VAZ, Gil Nuno. Marketing Institucional - 0 mercado de idéias e imagens. 2 ed. São Paulo: Pioneira, 2000.

VERGARA, S.C. Análise de conteúdo. In: Métodos de pesquisa em Administração. São Paulo: Atlas, 2005, cap. 1, p. 15-24.

WBCSD. Environmental performance and shareholder value. 1997. Disponível em <http://www.wbcsd.org >, acesso em 30 de março de 2010. 


\section{APÊNDICES}

\section{Apêndice A: Roteiro de entrevista}

1) Qual foi a metodologia aplicada na implementação do Sistema de Gestão Ambiental adotado pelo Pátio?

2) Que medidas foram adotadas, até o presente momento, nas atividades diárias desenvolvidas no âmbito do Pátio Brasil, no que tange a entrada, uso e saída de bens e serviços?

3) Em quanto tempo foi desenvolvido o SGA? Após a implementação, qual foi o tempo necessário para se adquirir a certificação?

4) O SGA recomenda o controle e auditoria das práticas de gestão ambiental. Como é realizado no Shopping? Há um setor responsável exclusivamente para este fim?

5) Quais os indicadores utilizados para mensurar os resultados obtidos com a implementação do Sistema?

6) No que concerne a Educação Ambiental, como é a relação entre a administração do shopping e os colaboradores lojistas?

7) Qual é a relação do Pátio Brasil com a Sonae Sierra?

8) Quais os impactos positivos ao meio ambiente decorrentes do SGA implantado pelo Pátio Brasil?

9) Quais impactos negativos ao meio ambiente o Pátio Brasil ainda pode evitar?

10) Qual o papel individual das lojas e do shopping no que tange à reciclagem 
de materiais (papel, latas de alumínio), seleção do lixo e eliminação de resíduos tóxicos? Existem incentivos à utilização de embalagens/sacolas reutilizáveis ou retornáveis?

11) Embora a certificação ambiental e as práticas de sustentabilidade sejam temas correntes, boa parte da população desconhece seu real valor. O Pátio Brasil incentiva o consumo de produtos que possuem certificação ambiental? Em caso positivo, como é feito esse incentivo e quais os valores agregados aos produtos e serviços que possuem certificação ambiental?

12) Um dos objetivos do SGA é alavancar os resultados financeiros, atuando na melhoria contínua de processos e serviços. O Pátio Brasil constatou aumento de faturamento relacionado ao SGA implementado?

13) O fato da Sonae Sierra ser conhecida como uma empresa que investe alto em sustentabilidade, tem gerado que vantagens para o shopping?

14) As diretrizes principais de gerenciamento da empresa são originárias do escritório matriz situado em Portugal?

15) Em sua opinião, Quais as principais razões que motivam um empresário a abrir uma loja no Pátio Brasil?

16) Em sua opinião, as ações ambientais promovidas pelo Pátio Brasil geram alguma influência na preferência do consumidor?

17) Como o senhor avalia a comunicação realizada pelo shopping acerca dos programas ambientais realizados? 


\section{Apêndice B: Questionário - Consumidores do Pátio Brasil}

1) Você frequenta ou já foi ao Pátio Brasil Shopping?

( ) Sim

( ) Não

2) Qual a sua faixa etária?

( ) 18 a 24 anos

( ) 25 a 34 anos

( ) 35 a 49 anos

( ) 50 a 60 anos

( ) Mais de 60 anos

3) Qual o seu grau de escolaridade?

( ) Fundamental incompleto

( ) Fundamental completo ou Médio incompleto

( ) Médio completo ou Superior incompleto

( ) Pós-graduação ou Superior completo

4) Você conhece as ações ambientais realizadas pelo Pátio Brasil?

( ) Não conheço

( ) Conheço apenas uma

( ) Conheço duas ou mais

5) Quando você efetua uma compra, dá preferência a produtos sustentáveis? *São os produtos ecologicamente corretos, economicamente viáveis e socialmente justos.

( ) Nunca

( ) Às vezes

( ) Sempre 
6) O fato de uma empresa ter a certificação ISO 14001 influencia em sua preferência?

ISO 14001 é a série de normas que estabelecem as diretrizes sobre a gestão ambiental dentro das empresas.

( ) Nunca

( ) Às vezes

( ) Sempre

7) As práticas ambientais de empresas como o Pátio Brasil já Ihe influenciaram mudando seus princípios ou costumes?

( ) Sim

( ) Não 